\title{
THE VALUE OF FPR INDICATOR IN DEPENDENCE OF DAIRY COWS' BODY CONDITION IN THE FIRST MONTH OF LACTATION
}

Department of Cattle Breeding and Milk Production, Wrocław University of Environmental and Life Sciences, Poland

\begin{abstract}
The research was performed on 100 cows of Black and White Polish Holstein-Friesian breed. The studied cows were under a visual and tactile evaluation of body condition using a BCS (Body Condition Scoring) method performed on the day of parturition as well as 30th day of lactation. The observation results of the body condition changes during that period were juxtaposed with FPR. The value of that indicator was determined on the base of control milking performed on the 30th day of lactation. The aim of the research was defining the relationship between the value of FPR and the changes of cows' body condition between the day of parturition and 30th day of lactation. The statistically significant differences $(P<0.05)$ of FPR value in dependence of the changes in cows' body condition between the parturition day and 30th day of lactation were determined.
\end{abstract}

Key words: BCS, milk, FPR, fat, protein.

\section{INTRODUCTION}

The cows' body condition has a significant influence on their production yield resulting in breeder's income. The emaciated cows as well as the fatty ones comprise the source of numerous problems being a decline in fertility and milk yield. An early problem detection, by means of condition analysis, simplifies and accelerates steps toward improving the animals' state of health as well as yield efficiency. One of the most significant production indicators is FPR, which is fat to protein ratio in milk. For healthy cows, the level of the indicator should remain between 1.1-1.3 (Reid et al. 1986; Jaquette et al. 1988; Perdon et al. 1993; Koeck et al. 2014; García et al. 2015). Values lower than 1.1 may suggest an acidosis and values above 1.3 may attest ketosis (Goff and Horst 1997; Drackley 1999; Rajala-Schultz et al. 1999; Enevoldsen et al. 2011; Koeck et al. 2014). It should be taken into consideration that clinical forms of the metabolic diseases may give severed symptoms. But in case of subclinical form (similarly to other diseases) the symptoms may be subtle what sometimes makes them

Corresponding author: Maciej Adamski, Department of Cattle Breeding and Milk Production Wrocław University of Environmental and Life Sciences, Institute Of Animal Breeding, Chełmońskiego 38C, 51-630 Wrocław, Poland, e-mail: maciej.adamski@upwr.edu.pl 
unrecognizable (Goff and Horst 1997; Drackley 1999, Rajala-Schultz et al. 1999; Enevoldsen et al. 2011; Koeck et al. 2014). One of subclinical acidosis as well as ketosis indicators are the changes in milk, including the PFR indicator (Reid et al. 1986; Duffield et al. 1997; Drackley 1999; Rajala-Schultz et al. 1999; Enevoldsen et al. 2011; Koeck et al. 2014; García et al. 2015).

The aim of the research was defining the relationship between the value of FPR and the changes of cows' body condition between the day of parturition and 30th day of lactation.

The distribution of calves was even throughout the year.

\section{MATERIAL AND METHODS}

The research was performed on 100 dairy cows of Black and White Polish Holstein-Friesian breed. The group comprised 72 multiparous cows and 28 primiparous cows. The animals were obtained from the farm placed in Lower Silesia Province and maintaining a herd of 451 cows and 219 heifers. The holding was under the milk performance testing. An average level of milk yield was $11,331 \mathrm{~kg}$, including $3.82 \%$ of fat and $3.35 \%$ of protein. The feeding of animals was based on TMR system supplemented by mineral lick enriched with cobalt, copper, zinc, iodine, manganese, magnesium, selenium and iron.

The studied cows were under a visual and tactile evaluation of body condition using a BCS (Body Condition Scoring) method. The fat reserves of the following body parts were evaluated: spinous and transverse processi of a lumbar spine, sacral ligament, short ribs area, tailhead, tailhead ligament, hooks, pins, thurl. Each part of the body was scored using 5-point scale with 0.25 point increments. The final score was a mean value of the scores of each evaluated body part. A score of 1 denoted a very thin cow, while 5 denotes an excessively fat cow. The evaluation of the cows' body condition was performed on the day of parturition as well as 30th day of lactation.

The observation results of the body condition changes during that period were juxtaposed with FPR. The value of FPR indicator was determined on the base of control milking performed on the 30th day of lactation.

The aim of the research was defining the relationship between the value of FPR and the changes of cows' body condition between the day of parturition and 30th day of lactation. The statistical relationship between the variables were verified using the Pearson's chi-square test (R-project 3.3.0 ®2016 program).

\section{RESULTS AND DISCUSSION}

The changes of body condition in a period between parturition day and 30th day of lactation were similar for multiparous and primiparous cows (Table 1). The differences between those groups were not statistically significant $(P>0.05)$. The average condition decrease during that period equaled 0.25 point (median 0.25 ), so it had corresponded the optimal range. According to literature that decrease should remain between 0.25-0.5 point ( Wildman et al. 1982; Parker 1989; Żarski and Arkuszewska 1999; Dobson and Smith 2000). In spite of optimal average condition decrease, the cases of rapid decrease of the body reserves were observed. 
The decrease by 0.75 point was noticed in 6 cows, while the decrease of body condition by 1 point was observed in 4 cows. In result, the over dynamic BCS decrease was observed in $10 \%$ of the herd $(n=10)$. However, for $30 \%$ of the studied animals $(n=30)$ body condition changes between parturition day and 30th day of lactation were not observed (Table 2).

Table 1. Fat to protein ration in tested herds

\begin{tabular}{|c|c|c|c|c|}
\hline \multirow{2}{*}{ Herds } & & \multicolumn{3}{|c|}{ Ratio TB 1} \\
\hline & & $0-1.48$ & 1.5 & $>1.5$ \\
\hline \multirow[b]{2}{*}{ Multiparous cows } & average TB 1 & 1.42 & 1.5 & 1.72 \\
\hline & $\begin{array}{l}\text { number of cows } \\
{[\%]}\end{array}$ & 62.5 & $\approx 9.7$ & $\approx 27.5$ \\
\hline \multirow[b]{2}{*}{ Primiparous cows } & avergae TB 1 & 1.34 & 1.51 & 1.68 \\
\hline & $\begin{array}{l}\text { number of cows } \\
{[\%]}\end{array}$ & $\approx 60.7$ & $\approx 7.1$ & $\approx 32.8$ \\
\hline
\end{tabular}

Table 2. Basic herd statistics

\begin{tabular}{|c|c|c|c|c|c|c|c|c|c|}
\hline Herd & $\begin{array}{c}\text { Average } \\
\text { BCS } \\
\text { before } \\
\text { labor }\end{array}$ & $\begin{array}{c}\text { Average } \\
\text { BCS after } \\
\text { labor }\end{array}$ & FPR & $\begin{array}{c}\text { Standard } \\
\text { deviation } \\
\text { BCS } \\
\text { before } \\
\text { labor }\end{array}$ & $\begin{array}{c}\text { Standard } \\
\text { deviation } \\
\text { BCS after } \\
\text { labor }\end{array}$ & $\begin{array}{c}\text { Variance } \\
\text { BCS } \\
\text { before } \\
\text { labor }\end{array}$ & $\begin{array}{c}\text { Variance } \\
\text { BCS after } \\
\text { labor }\end{array}$ & $\begin{array}{l}\text { Correlation } \\
\text { BCS to } \\
\text { FPR before } \\
\text { labor }\end{array}$ & $\begin{array}{c}\text { Correlation } \\
\text { BCS to FPR } \\
\text { after labor }\end{array}$ \\
\hline $\begin{array}{l}\text { Multipa- } \\
\text { rous cows }\end{array}$ & 3.48 & 3.05 & $\begin{array}{c}\leq 1.48 \\
\approx 62.5 \% \\
1.5 \approx 9.7 \% \\
\geq 1.5 \\
\approx 27.5 \%\end{array}$ & 0.812 & 0.647 & 0.659 & 0.419 & -0.086 & -0.029 \\
\hline $\begin{array}{l}\text { Primipa- } \\
\text { rous cows }\end{array}$ & 4.12 & 3.46 & $\begin{array}{c}\leq 1.48 \\
\approx 60.7 \% \\
1.5 \approx 7.1 \% \\
\geq 1.5 \\
\approx 32.8 \%\end{array}$ & 0.753 & 0.565 & 0.566 & 0.320 & 0.655 & 0.567 \\
\hline
\end{tabular}

Within the analyzed group of the cows the value of FPR indicator remained between 0.77-2.26. Therefore, there were cases of deviation from reference values (1.1-1.3) among the group of studied animals. However, the mean value of FPR indicator for the studied cows was 1.24 (median 1.2), which corresponded to optimal range. The cows with the FPR indicator lower than 1.1 in 30th day of lactation constituted $21 \%$ of a group $(n=21)$. None of those animals manifested the clinical symptoms of clinical acidosis. However, the results might suggest the subclinical form of that disorder.

The cows with fat to protein ratio reaching above 1.3 constituted $19 \%$ of analyzed group. The clinical form of ketosis was noticed in 4 cases, which constituted $21 \%$ of animals with increased FPR. The elevated FPR value in other cases could suggest the subclinical form of ketosis. 
The statistically significant differences $(P<0.05)$ of FPR value in dependence of the changes in cows' body condition between the parturition day and 30th day of lactation. The BCS decrease of the cows with optimal fat to protein ratio in milk remained between $0.25-0.5$ point.

All cows with FPR lower than $1.1(n=21)$ did not manifest anybody condition changes between the day of parturition and 30th day of lactation. It indicates that in case of $70 \%$ of the cows with no body condition changes the decreased FPR value was observed. It may be suggested that cows not manifesting the body reserves changes between the parturition day and the 30th day of lactation might be predisposed to subclinical form of acidosis.

However, in a group of animals with increased fat to protein ratio in milk ( $>1.3$ ) the cows with rapid body condition decrease $(0.75-1$ point) were the majority. They constituted $53 \%$ ( $n=10$ ) of the cows with high FPR value. Within that group the BCS decrease was manifested in $42 \%(n=8)$ of cows by 0.5 point and $5 \%(n=1)$ of them by 0.25 point.

The results of the self performer research correspond with the results of numerous authors (Wildman et al. 1982; Jaquette et al. 1988; Edmondson et al. 1989; Perdon et al. 1993; Duffield et al. 1997, Drackley 1999; Rajala-Schultz et al. 1999; Enevoldsen et al. 2011; Koeck et al. 2014).

\section{SUMMARY AND CONCLUSIONS}

The body condition scoring of the dairy cows is simple and effective method of body reserves evaluation. Maintaining the cows in condition optimal for particular physiological phases allows to minimize the risk of many disorders. The self performed research indicates that keeping the cows in a proper condition allows to decrease the risk of metabolic diseases. However, it should be taken under consideration that a state of body reserves is not the most important, but its dynamic of changes between the day of parturition and 30th day of lactation is important. It has a major impact on healthiness of dairy cows. Over rapid decrease of the condition as well as its absence constitute a risk of metabolic disorders, especially ketosis and acidosis. Those diseases may occur in clinical form as well as the subclinical one. It should be stressed that subclinical forms of them might be inconvenient to recognize. Those forms manifest subtly but they cause unprofitable changes. They deteriorate cows' healthiness and cause economic losses. This is a result from the fact of deterioration of milk quality, cows' milking yield decrease and cost of veterinary treatment. Therefore, it is important to make every effort to maintain the cows in optimal body condition in every stage of production, especially during the dry period and early lactation.

It should be pointed out that BCS as well as the evaluation of healthiness shall not be performed on a group basis. Obviously it suitable for herd monitoring, however the individual basis is more recommended. Treating the herd as the single model may result in unrecognizing the pathological cases. As the self performed research indicated, in spite of normal values of the indicators for the group, the extreme values of those indicators were observed.

\section{REFERENCES}

Dobson H., Smith R.F. 2000. What is stress and how does it affect reproduction? Anim. Reprod. Sci. 60, 743-752. 
Drackley J.K. 1999. ADSA foundation Scholar Award: Biology of dairy cow during the transition period: The final frontier. J. Dairy Sci. 82, 2259-2273.

Duffield T., Kelton D., Leslie K., Lissemore K., Lumsden H. 1997. Use of test day milk fat and milk protein to detect subclinical ketosis in dairy cattle in Ontario. Canad. Vet. J. 38(11), 713-718.

Edmondson A.J., Lean I.J., Weaver L.D., Farrer T., Webster G. 1989. A body condition scoring chart of Holstein dairy cows. J. Dairy Sci. 72, 69-78.

Enevoldsen C., Krogh M., Toft N. 2011. Latent class evaluation of a milk test, a urine test, and the fatto-protein percentage ratio in milk to diagnose ketosis in dairy cows. J. Dairy Sci. 94(5), 2360-2367.

García C.A.C., Montiel R.L.A., Borderas T.F., Girard V. 2015. Relationship between $\beta$-hydroxybutyrate and the fat: protein ratio of milk during early lactation in dairy cows. Arch. Med. Vet.47(1), 21-25.

Goff J.P., Horst R.L. 1997. Physiological changes at parturition and their relationship to metabolic disorders. Physiology and management. J. Dairy Sci. 80, 1260-1268.

Jaquette R.D., Rakes A.H., Croom Jr W.J. 1988. Effects of body condition and protein on milk fat depression in early lactation cows. J. Dairy Sci. 71, 2123-2134.

Koeck A., Jamrozik J., Schenkel F.S., Moore R.K., Lefebvre D.M., Kelton D.F., Miglior F. 2014. Genetic analysis of milk $\beta$-hydroxybutyrate and its association with fat-to-protein ratio, body condition score, clinical ketosis, and displaced abomasum in early first lactation of Canadian Holsteins. J. Dairy Sci. 97(11),7286-7292.

Parker R. 1989. Using body condition scoring in dairy herds management. OMAF Factsheet 410(20), 88-89.

Perdon O., Federicia C.H., Senatore E., Baroli D., Rizzi R. 1993. Effect of body condition score at calving on performance, some blood parameters and milk fatty acid composition in dairy cows. J. Dairy Sci. 76, 2528-2535.

Rajala-Schultz P.J., Grohn Y.T., McCulloch C.E. 1999. Effect of milk fever, ketosis, and lameness on milk yield in dairy cows. J Dairy Sci. 82, 288-294.

Reid I.M., Roberts C.J., Teacher R.J., Williams L.A. 1986. Effect of body condition at calving on tissue mobilisation, development of fatty liver and blood chemistry of dairy cows. Anim. Prod. 43, 7-15.

Wildman E.E., Jones G.M., Wagner P.E., Boman R.L., Troutt H.F., Lesch T.N. 1982. A dairy cow body condition scoring system and its relationship to selected production characteristics. J. Dairy Sci. 65, 495-502.

Żarski T.P., Arkuszewska E. 1999. Zespół zwyrodnienia tłuszczowego wątroby krów mlecznych. Prz. Hod. 6, 8-9.

\section{WARTOŚĆ WSKAŹNIKA TB1 W MLEKU W ZALEŻNOŚCI OD KONDYCJI CIAŁA KRÓW MLECZNYCH W PIERWSZYM MIESIACCU LAKTACJI}

Streszczenie. Badania przeprowadzono na krowach rasy holsztyńsko-fryzyjskiej odmiany czarno-białej. Badane krowy poddano palpacyjno-wzrokowej ocenie kondycji ciała, metodą BCS, w dniu porodu oraz w 30 dniu laktacji. Uzyskane wyniki obserwacji zmiany kondycji ciała w tym okresie zestawiono ze wskaźnikiem TB1. Wskaźnik ten był określony na podstawie próbnego udoju wykonanego w 30 dniu laktacji. Celem badań było stwierdzenie zależności pomiędzy zmianą kondycji ciała krów w pierwszym miesiącu po porodzie a wskaźnikiem TB1 w 30 dniu laktacji. Stwierdzono różnice istotne statystycznie $(p<0,05)$ wartości TB1, w zależności od stopnia zmiany kondycji ciała krów między okresem okołoporodowym a 30 dniem laktacji.

Słowa kluczowe: BCS, krowy, mleko, TB1, białko tłuszcz. 
